\title{
The Politics of European Union Climate Governance
}

Paul Mollet, Saleh Al Muhanna and AlJawhara Al Quayid 


\section{About KAPSARC}

The King Abdullah Petroleum Studies and Research Center (KAPSARC) is a non-profit global institution dedicated to independent research into energy economics, policy, technology and the environment across all types of energy. KAPSARC's mandate is to advance the understanding of energy challenges and opportunities facing the world today and tomorrow, through unbiased, independent, and high-caliber research for the benefit of society. KAPSARC is located in Riyadh, Saudi Arabia.

\section{Legal Notice}

(C) Copyright 2018 King Abdullah Petroleum Studies and Research Center (KAPSARC). No portion of this document may be reproduced or utilized without the proper attribution to KAPSARC. 


\section{Key Points}

The United Kingdom (UK) exit (Brexit) from the European Union (EU) is likely to strengthen the resolve of the EU to maintain global leadership at the Conference of Parties (COP).

Brexit is likely to contribute a changed approach toward climate policy from a focus on market instruments to policy targets.

A struggle has emerged for leadership within the Green Growth Group, with many coalition members seeking more ambitious climate targets.

Despite some changes in governments, the national climate position of EU member states remains stable.

Poland, perhaps supported by other coal-dependent countries, is likely to remain an obstacle to more ambitious EU climate targets.

Environmental coalitions within the European Union.

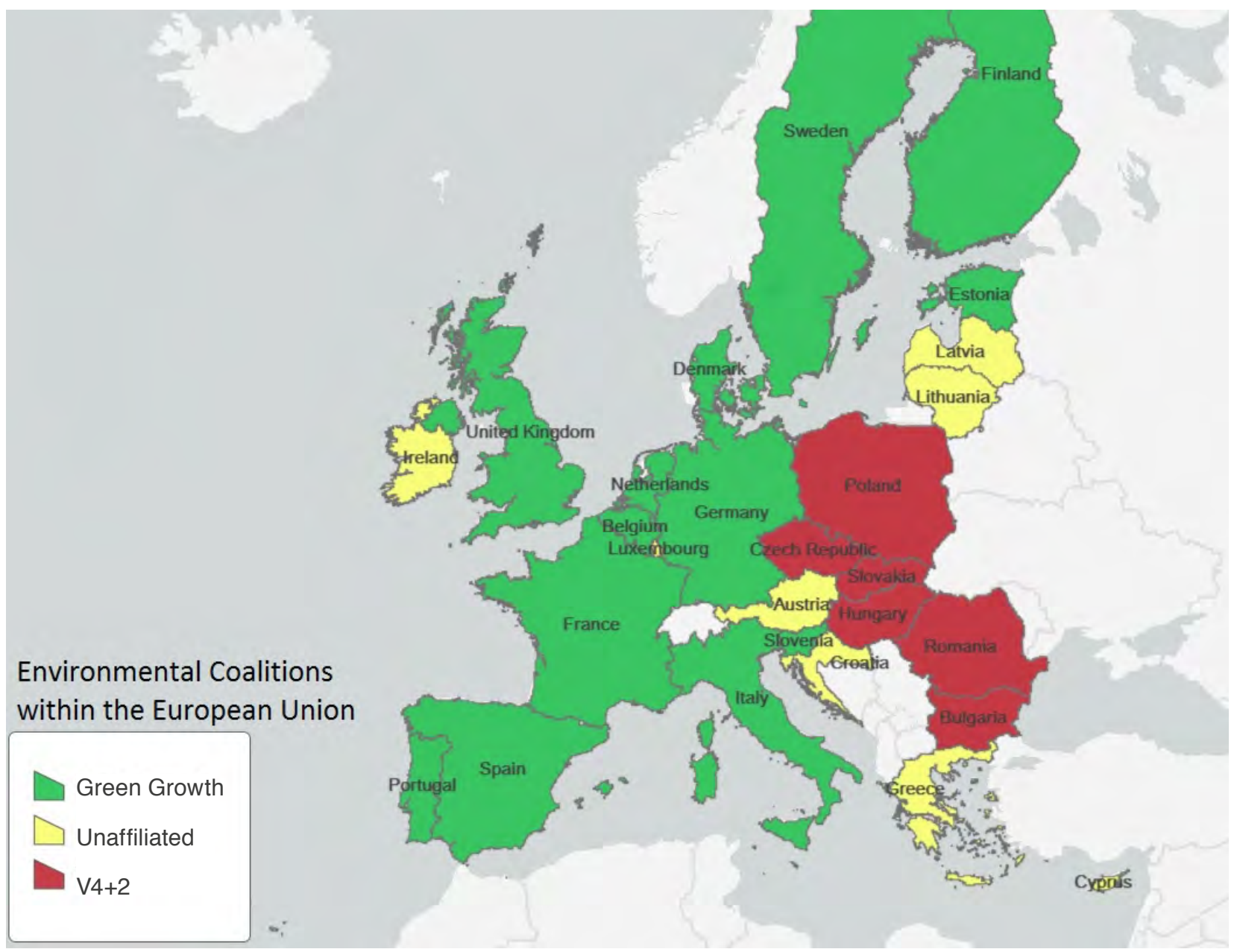

Source: KAPSARC WebGIS. 


\section{Summary}

The European Union (EU) is facing a critical period as the European Commission draws up a 2050 climate strategy roadmap that is likely to form the basis for the EU's next nationally determined contribution to the COP21 Paris Agreement. Until recently, the UK was the undisputed leader of the coalition of EU member states (the Green Growth Group) seeking more ambitious climate targets. Brexit, however, is likely to put an end to the UK-driven focus on market instruments to achieve climate targets. Instead, the Commission is now likely to turn to policies prioritizing emissions and energy targets. A struggle for leadership of the Green Growth Group has emerged, with France, the Netherlands and Sweden vying for greater protagonism at a time when Germany is increasingly absent from the climate debate. Recent government changes in Spain, Italy and Austria appear to have little effect on each country's respective climate policy; both Spain and Italy remain in the progressive camp while Austria is taking a more nuanced position. In contrast, Poland continues to hold out against a toughening of emissions targets because of its reliance on coal, but its historic support from other Visegrád Group members could be weakening.

Despite these internal differences, overall EU states seem determined to maintain Europe's moral leadership of the global climate change debate and the Commission is expected to reveal the first draft of its 2050 roadmap at the upcoming COP24 in Katowice, Poland. This will give an indication of the direction the EU's climate policy is likely to take over the coming decades. 


\section{Introduction}

O ver the last decade, the European Union (EU) has been at the forefront of the global effort to combat climate change. Within the Conference of the Parties (COP) of the United Nations Framework Convention on Climate Change (UNFCCC), the EU acts as a single entity, submitting a single nationally determined contribution (NDC). In turn, climate change falls under the direct mandate of the EU, with member states obliged to follow targets agreed through the EU's internal governance process. As a result, many EU members rank globally among the countries with the most ambitious climate targets.

Yet, climate-related legislation is one of the most hotly-contested areas in the Union due to the economic cost of mitigation measures and the fact that some countries are structurally locked into highemission economies. This conflict is exacerbated by internal EU rules dictating that climate measures are decided by qualified majority vote, while national energy mixes are considered a matter of national sovereignty and normally agreed to unanimity.

Transitioning the overall EU energy mix away from coal towards renewables is a key plank of many proposed EU measures, but member states are divided in their support.

Such a transition would have particularly severe impacts on many countries in central and eastern Europe that historically have generated power using coal, resulting in high per-capita emissions. This is true notably for the Visegrád Group (the Czech Republic, Hungary, Poland and Slovakia) as well as for Bulgaria and Romania. These countries are fighting a rearguard action against proposals that would have an impact on their legacy energy mix. In Poland, for example, coal not only provides cheap fuel but also supports a large number of mining jobs.

On the pro-transition side is a coalition of member states that are either wealthy (and thus able to absorb the costs of climate measures) or already have a high proportion of non-fossil fuel energy (such as nuclear and renewables). This group of countries, known as the Green Growth Group, includes Belgium, Denmark, Estonia, Finland, France, Germany, Italy, the Netherlands, Portugal, Slovenia, Spain, Sweden and the United Kingdom (UK). 


\section{KAPSARC Assesses the Political Feasibility of NDCs for High Emitters}

ollective efforts to limit the global temperature increase to 2 degrees Celsius above pre-industrial levels (or, indeed, achieve the even more ambitious 1.5 degrees Celsius objective) will be determined not only through technical solutions that facilitate the reduction of carbon dioxide $\left(\mathrm{CO}_{2}\right)$ emissions in energy systems, but also by a combination of domestic political constraints and geopolitical considerations. A shift towards low-carbon energy carries financial costs; the consequent reshaping of industries is likely to redistribute wealth among signatories of the Paris Agreement.

As a result, the way forward is likely to be fraught with political challenges. In the near term (i.e., by 2020), the opportunity exists for signatories to after an ongoing stock-taking process - enhance their NDCs. This brings to the fore the challenges associated with incentives to enhance current NDCs, and to implement those committed to now and in the future.
KAPSARC is undertaking a large research effort to assess the political feasibility of implementing and enhancing NDCs - particularly with respect to greenhouse gas (GHG) emissions. The project will combine quantitative and qualitative methods to provide insights into the opportunities and challenges inherent in the Paris Agreement. Focusing on the top five emitters - China, the United States, the EU, India and Russia - the project will investigate the domestic and/or regional politics of emissions and the relevant NDCs. The project will also broaden its scope to a global assessment that considers the geopolitical factors that play into national decision-making processes. The methodological approach combines field research (in the form of structured interviews with subject matter experts in each of five countries/ regions) with a simulation of the collective decisionmaking processes (CDMPs) using the KAPSARC Toolkit for Behavioral Analysis (KTAB). KTAB utilizes expert data regarding actors and stakeholders who influence decision-making processes to evaluate the range of politically acceptable outcomes. 


\section{Gathering Insights on the EU State of Play}

$\mathrm{T}$

his paper draws on insights obtained through expert interviews to provide a snapshot of the current political environment in the EU, including a description of the various factions and interests competing to shape the future of the EU's role in the Paris Agreement. This sets the stage for a future paper that will detail findings of the KTAB simulation of the EU decisionmaking process going forward.

Topic experts consulted for this study reflect a range of views from within the EU. To facilitate candid conversation, interviews were conducted with the explicit agreement that specific answers would not be attributed to particular experts. Additionally, experts were given the opportunity to keep their contribution completely anonymous. Eleven subject matter experts were interviewed between March and June 2018:

Murray Birt, Vice President, DWS Group.

Anthony Froggatt, Senior Research Fellow, Chatham House.

Jonathan Gaventa, Director, E3G.

Pete Harrison, Transport Program Director, European Climate Foundation.
Erica Hope, Senior Associate, European Climate Foundation.

Francois-Regis Mouton, Director EU Affairs, International Association of Oil and Gas Producers.

Carlos Ochoa, Senior Director, Strategic Communications, FTI Consulting.

Kamila Piotrowska, EU Affairs Manager, International Association of Oil and Gas Producers.

Nareg Terzian, Media and EU Affairs Manager, International Association of Oil and Gas Producers.

Shane Tomlinson, Director, E3G.

Coby van der Linde, Director, Clingendael International Energy Programme, Clingendael Institute.

The remainder of this paper synthesizes the insights of these 11 experts based on interviews conducted by the KAPSARC team. 


\section{EU Climate Politics: Early Leadership by the UK}

$\mathrm{T}$ he UK has long been a leader in the EU climate debate. In November 2008, the UK passed the Climate Change Act, becoming the first EU member state to pass specific legislation with statutory long-term emissions targets and short-term $\mathrm{CO}_{2}$ budgets. This Act signaled the UK's commitment to combating the effects of climate change and established the country as the undisputed leader of a 'progressive' coalition of member states aiming to commit the
EU to more ambitious and binding emission caps. Since then, only Sweden has enacted legislation (in 2018) that includes long-term mandatory caps on national $\mathrm{CO}_{2}$ emissions (Figure 1).

The Green Growth Group was launched in 2013, an initiative led by the then UK Secretary of State for Energy and Climate Change, Ed Davey. Its first report, Going for Green Growth, called for an ambitious EU 2030 Energy and Climate Policy

Figure 1. Environmental coalitions within the European Union.

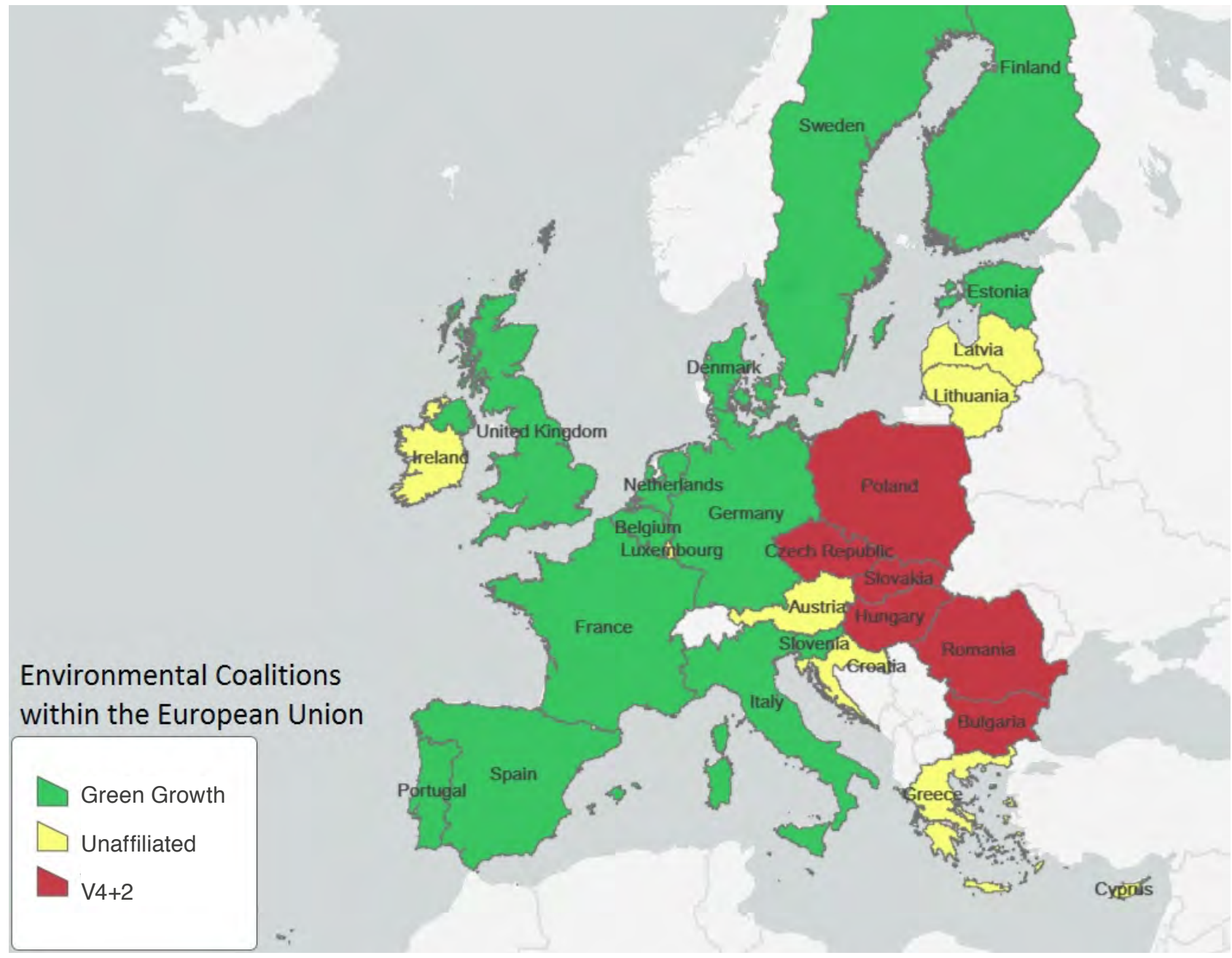

Source: KAPSARC WebGIS. 
Framework and for a structural reform of the EU's Emissions Trading System, both of which were realized in subsequent years.

During this period, the UK was the undisputed leader of the progressive coalition, using this position to impose on EU policymakers its own vision of combining market-oriented approaches and global $\mathrm{CO}_{2}$ emissions targets while vehemently opposing specific energy targets, notably those covering renewables and energy efficiency. UK officials also provided the secretariat to the Green
Growth Group, ensuring that meetings took place at strategically important times and setting the agenda for discussions.

Following the election of a new Conservative UK government in 2015, the external profile of the Green Growth Group waned, though former UK officials insist that senior officials and ministers from countries in the group were in constant email contact and continued to meet regularly to coordinate policy positions prior to key Council meetings. 


\section{The Brexit Effect on EU Climate Policy}

The UK decision (March 27, 2017) to invoke Article 50 of the Treaty of European Union, allowing for withdrawal of member states from the Union, has severely weakened the country's leadership role within the coalition of EU member states favoring more ambitious climate targets. In fact, the UK's scheduled exit from the EU on March 29, 2019 is prompting a realignment within the Green Growth Group, with other member states now jockeying for position as the EU's new climate champions. The outcome could have major implications for the future direction of the grouping's energy and climate policies - and could possibly alter the direction of the Union's climate policy.

Following a brief period of uncertainty over its future operations, the Green Growth Group has recently been galvanized with countries clearly keen to maintain the momentum for progress on climate change post-Brexit. France quickly jumped into the breach left by the UK, convening the group to issue a statement on March 5, 2018 on a relatively minor technical issue related to financing EU climate action. In particular, the statement called for reinforcing climate spending and mainstreaming the next Multiannual Financial Framework. In April 2018, France led a call by seven EU environment ministers (Finland, France, Germany, Luxembourg, the Netherlands, Portugal and Sweden) for greater climate ambition and global leadership from the Union. A similar call from the entire Green Growth Group for stronger EU climate action was made on June 25, 2018, coinciding with a meeting of the EU Environment Council in Luxembourg.
While France can claim a degree of moral leadership in the climate debate due to its coordinating role in securing the Paris Agreement, some members of the Green Growth Group, notably Scandinavian countries and the Netherlands, are likely to resist the emergence of a leader likely to impose its own policy preferences, as the UK did in resisting renewables targets. The group is likely to emerge as a looser - but more active - coalition, with a rotating secretarial function.

Germany, though a committed member of the group, remains at present firmly on the sidelines. The Merkel coalition government is currently more focused on domestic issues, notably migration. In June 2018, the government admitted that it would miss its own climate targets for 2020. Germany's flagship energy policy, termed Energiewende, involved the closure of nuclear plants and promoting renewable energy. Ironically, it had the unintended consequence of undermining its own targets. The price signals that arose from this policy have had the perverse effect of encouraging coal-fired power at the expense of natural gas; as a result, emissions reductions from increased renewables have been offset by higher emissions from coal. Faced with ongoing political squabbles, the Merkel coalition has allowed energy and climate policy to fall largely by the wayside. Within EU negotiations, Germany still supports a targetbased approach that favors renewables and energy efficiency over other technologies. 


\section{Environment Policies Remain Stable Despite Government Changes}

espite dramatic changes across Europe's political landscape in the past year, national environmental policies have remained remarkably unaltered. Membership of the Green Growth Group remains largely unchanged. In fact, recent incoming governments have, if anything, shown greater commitment to stronger climate measures. Spain's new energy and environment minister, Teresa Ribera, has signaled her commitment to tighter EU climate targets. In his inaugural speech, Italy's new Prime Minister Giuseppe Conte called for increased decarbonization of the country's energy production system. Portugal's newish left-wing coalition actively promotes a progressive climate agenda on the EU stage. Only Austria, a nominal member of the group, remains on the fence: the new right-wing government signed up to the group's call on climate financing but stopped short of calling for greater EU commitment on climate change. 


\section{Post-Brexit Impacts on EU Policy Already Evident}

The UK's loss of influence following the launch of the Brexit process has already had concrete policy impacts. In June 2018, EU energy ministers agreed to a binding renewable energy target of 32 percent by 2030, up from the previous non-binding goal of 27 percent. The switch from a non-binding to a mandatory target, coupled with the increase in the target, is the first clear example of a change in policy direction in the wake of Brexit. Previously, the UK resisted mandatory targets, preferring instead carbon emission caps that gave each country flexibility in the policy used to achieve such targets and left much to market forces. The new target was the level advocated by France but fell below the 35 percent argued for by new governments in Spain and Italy.

The 2050 climate strategy roadmap, which the European Council instructed the European Commission to draw up by the end of the first quarter of 2019, will be a key indicator of the EU's new climate policy landscape. In parallel, the Commission is under pressure to set its long-term proposals before the COP24 meeting in Katowice (Poland) in December 2018. The new long-term strategy will replace the 2050 low-carbon economy roadmap published in 2011, which set an indicative target of an 80 percent cut in $\mathrm{CO}_{2}$ emissions by 2050.

Countries in the Green Growth Group want the Commission to revisit the EU targets set for 2030 and to update its NDC by 2020. The existing NDC has a binding target of at least a 40 percent reduction in domestic GHG emissions by 2030 (compared with 1990); the group believes that current and planned efforts justify increasing this target. Ultimately, the UK withdrawal from the EU climate governance process is unlikely to significantly weaken the Green Growth Group's influence, in part because its members still represent a majority voting block within the EU.

The block led by Poland, in contrast, is relatively weak despite the fact that the nature of EU measures to tackle climate change puts this issue much higher on the political agendas of these countries compared with other EU members. The Visegrád Group has been noticeably weakened in recent months, not least by the challenge posed by Poland and Hungary to core European values such as liberalism and the rule of law. The Czech Republic and Slovakia are unwilling to align themselves on such issues, creating cracks in the alliance. In June, the Czech deputy environment minister called for more funding for clean energy programs, a suggestion that confirms a widely held belief that poorer EU countries will accept more aggressive climate targets so long as financing is available to pay for the necessary measures. Even Poland appears to be preparing for more ambitious EU-wide climate change targets. Increasingly, officials are talking about the EU aggregating national plans, suggesting that Poland is seeking a mechanism that allows it to underperform in relation to other EU member states.

Rather than weakening the EU's climate aspirations, Brexit might well end up strengthening the Union's resolve.

The UK has made clear its intent to remain a global climate leader in a post-Brexit world. In April 2018, the government announced it was establishing an independent committee to review the country's 2050 goal, with a possible view to strengthening its 
targets. As the EU is unlikely to want to be seen as a laggard, such a move may encourage the Union to aim for more ambitious climate aspirations. Two key political events next year, the nomination of a new European Commission and elections for the European Parliament (which 'co-decides' climate policy with the European Commission and the European Council) could disrupt the Union's momentum towards greater efforts to combat climate change but seem unlikely to do so. 


\section{Notes}




\section{About the Authors}

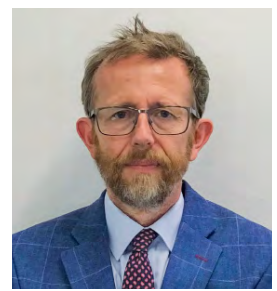

\section{Paul Mollet}

Paul is a research fellow in KAPSARC's Policy and Decision Sciences program. He is an analyst with over 25 years of experience covering international oil and energy markets. Paul has attended numerous OPEC meetings and written extensively about the oil industry in publications such as Platts Oilgram News, Argus Global Markets, and the Petroleum Economist.

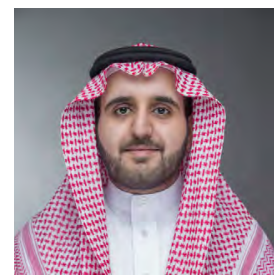

\section{Saleh Al Muhanna}

Saleh is a senior research analyst in the Policy and Decision Science program with interests in geopolitical research, international agreements and international trade. He holds a master's degree in international commerce and policy from George Mason University and a B.S. degree in economics from the Pennsylvania State University.

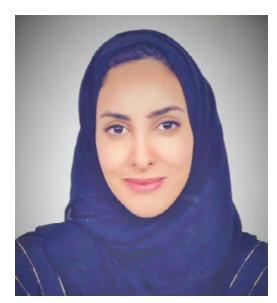

\section{Aljawhara AI Quayid}

AlJawhara is a research analyst in the Policy and Decision Science program with research interests in political economy, international affairs, geopolitics, and finance and trade. She is currently working on the Political Feasibility of Nationally Determined Contributions Under the Paris Agreement project, and on the KAPSARC Toolkit for Behavioral Analysis (KTAB). 
INAPSARC

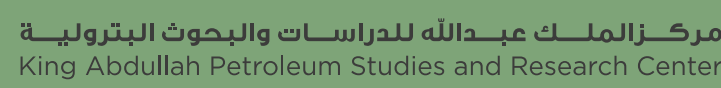

www.kapsarc.org 